\title{
Extremely Low Birth Weight
}

National Cancer Institute

\section{Source}

National Cancer Institute. Extremely Low Birth Weight. NCI Thesaurus. Code C114936.

Birth weight less than 1000 grams. 